\title{
Perbandingan Durasi Waktu Proyek Konstruksi Antara Metode Critical Path Method (CPM) dengan Metode Critical Chain Project Management (Studi Kasus: Proyek Pembangunan Apartamen Menara Rungkut)
}

\author{
Mohamad Aulady ${ }^{[1]}$, Cesaltino Orleans ${ }^{[2]}$ \\ Jurusan Teknik Sipil-InstitutTeknologi Adhi Tama Surabaya ${ }^{[1][2]}$ \\ Email : mohamadaulady@itats.ac.id
}

\begin{abstract}
The schedule delays on construction project is one of the case that inflict a financial loss towards stakeholders. Critical Chain Project Management (CCPM) is a scheduling methode that can be alternative solution from schedule controlling. This methode is done by reducing the multitasking, student syndrom, parkinson's law and giving the buffer in the end of time project. The aim of this study is comparing CCPM methode to Critical Path Methode (CPM) methode on Menara Rungkut apartment construction, Surabaya. CPM its self is the traditional project schedule that still use alternative time on each activity to protect the activities. The initial project schedule employ the traditional schedule methode by gantt chart that is then divided into detail and comprehensive by the relation among their activites in CPM form. Futhermore, it will be compared to CPPM schedule result that have reduced multitasking, safetytime on each activity and have given buffer on their work. Compared to the times, this study elucidate time duration for CCPM is 121 days that 48 days prior to CPM methode.
\end{abstract}

Keywords : Time duration, CCPM, CPM, the end of time project, traditional schedule.

\begin{abstract}
ABSTRAK
Keterlambatan jadwal pada proyek konstruksi merupakan salah satu masalah yang dapat merugikan berbagai pihak pada proyek. Critical Chain Project Management (CCPM) adalah suatu metode penjadwalan yang dapat menjadi solusi alternatif dari permasalahan pengendalian jadwal tersebut. Metode ini ditempuh dengan cara menghilangkan multitasking, student syndrome, parkinson's law serta memberi buffer di waktu akhir proyek. Penelitian ini bertujuan untuk membandingkan metode $C C P M$ tersebut dengan metode Critical Path Method (CPM) pada studi kasus proyek Pembangunan Apartamen Menara Rungkut, Surabaya yang tengah berjalan. CPM sendiri adalah metode penjadwalan tradisional yang masih menggunakan waktu cadangan pada setiap aktivitas untuk melindungi aktivitas-aktivitasnya. Penjadwalan awal proyek menggunakan metode penjadwalan tradisional berupa gantt chart yang kemudian di-breakdown lebih detail dan lengkap dengan hubungan antar aktivitasnya ke dalam bentuk $C P M$, dan kemudian akan dibandingkan dengan hasil dari penjadwalan CCPM yang telah menghilangkan multitasking, menghilangkan Safety time pada tiap aktivitas dan memberi buffer dalam pengerjaannya. Dibandingkan dari segi waktu, hasil penelitian ini didapatkan durasi waktu untuk CCPM adalah 121 hari lebih cepat 48 hari jika dibandingkan dengan metode CPM.
\end{abstract}

Kata Kunci : Durasi Waktu, CCPM, CPM, waktu akhir proyek, penjadwalan tradisional.

\section{PENDAHULUAN}

Konflik utama yang sering dihadapi dalam sebuah proyek konstruksi adalah penjadwalan proyek [1]. Penjadwalan proyek merupakan salah satu elemen penting, karena penjadwalan memberikan informasi tentang kemajuan proyek dalam hal kinerja sumber daya, biaya, tenaga kerja, peralatan, material serta rencana durasi proyek dan progres waktu untuk penyelesaian proyek [2]. Progres waktu yang ditampilkan dalam jadwal proyek menjadi salah satu elemen penting dalam pengendalian waktu proyek. Karena dengan mengetahui progres rencana dana aktual satu proyek, maka kita dapat mengetahui seberapa jauh proyek tersebut terlambat atau lebih cepat. Seperti masalah penjadwalan yang dialami oleh proyek Pembangunan Apartemen Menara Rungkut. Di mana proses pembangunan pada lantai 8 dan 9 tidak sesuai schedule (terlambat), terutama pada saat pelaksanaan bekisting. Pekerjaan bekisting membutuhkan waktu yang cukup lama yaitu 12-14 hari 
per lantai. Baik buruknya pekerjaan pemasangan bekisting sangat berpengaruh pada mutu dan kualitas beton. Oleh karena itu penjadwalan harus di kontrol dengan baik dan benar. Karena jika pekerjaan bekeisting tertunda atau terlambat, maka pekerjaan pengecoran juga bisa terlambat dan dapat pula berpengaruh pada mutu beton.

Untuk mengatasi hal ini penulis mencoba menerapkan metode Critical Chain Project Management (CCPM) yang merupakan penerapan Theory of Constrain (TOC) dalam manajemen proyek. Dalam metode ini, proyek dapat dipandang sebagai sebuah sistem, dan setiap sistem mempunyai konstrain. Dalam proyek, keterbatasan sumber daya merupakan konstrain utama yang menghambat penyelesaian proyek secara lebih cepat. CCPM menerapkan langkah-langkah TOC untuk merekayasa manajemen pelaksanaan proyek.

\section{TINJAUAN PUSTAKA}

\section{Penjadwalan}

Jadwal proyek merupakan alat yang dapat menunjukkan kapan berlangsungnya setiap kegiatan, sehingga dapat digunakan untuk pengendalian pelaksanaan proyek secara keseluruhan [3]. Dalam penelitian lain, penjadwalan atau scheduling adalah pengalokasian waktu yang tersedia untuk melaksanakan masing-masing pekerjaan dalam rangka menyelesaikan suatu proyek hingga tercapai hasil optimal dengan mempertimbangkan keterbatasan - keterbatasan yang ada [2]. Penjadwalan proyek merupakan salah satu elemen penting [2]. Karena penjadwalan memberikan informasi tentang kemajuan proyek dalam hal kinerja sumber daya berupa biaya,tenaga kerja,peralatan dan material serta rencana durasi proyek dan progres waktu untuk penyelesaian proyek. Penjadwalan sering terlambat dikarenakan karena pengelola proyek kurang memahami jadwal proyek dan kurangnya komunikasi antara pengelola dengan pekerja di lapangan [4].

\section{Critical Path Method (CPM)}

CPM (Critical PathMethod) adalah metode penjadwalan tradisional yang masih menggunakan waktu cadangan pada setiap aktivitas untuk melindungi aktivitas-aktivitas tersebut [5]. $C P M$ atau disebut juga metode jalur kritis merupakan salah satu metode yang menggunakan estimasi waktu secara deterministik. Jalur (lintasan) kritis suatu proyek adalah jalur dalam suatu jaringan kerja sedemikian hingga kegiatan pada lintasan ini memiliki kelembanan nol [6]. Jaringan kerja merupakan salah satu metode yang menjelaskan hubungan antara kegiatan dan waktu yang secara grafis mencerminkan urutan rencana kegiatan atau pekerjaan proyek [5]. Kegunaan jalur kritis tersebut untuk mengetahui kegiatan yang memiliki kepekaan sangat tinggi atas keterlambatan penyelesaian pekerjaan, atau disebut juga kegiatan kritis. Apabila kegiatan keterlambatan proyek maka akan memperlambat penyelesaian proyek secara keseluruhan meskipun kegiatan lain tidak mengalami keterlambatan.

\section{Perhitungan Jalur Kritis}

Perhitungan jalur kritis mencakup dua tahap. Tahap pertama disebut perhitungan maju (forward pass), di mana perhitungan dimulai dari node "awal" dan bergerak ke node "akhir". Di setiap node, sebuah angka dihitung yang mewakili waktu yang tercepat untuk suatu kejadian yang bersangkutan. Tahap kedua yang disebut perhitungan mundur (backward pass), memulai perhitungan dari node "akhir" dan bergerak ke node "awal" [7].

\section{Perhitungan Maju}

Pada perhitungan maju dimaksudkan untuk menghitung saat yang paling awal terjadinya dan penyelesaian kegiatan suatu proyek. Waktu mulai paling awal ES (Earliest Start Time) suatu kegiatan j didapatkan dari rumus: 
Di mana:

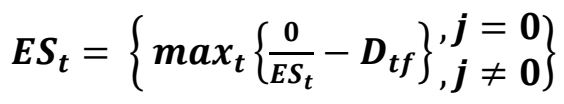

$E S_{j}$ adalah waktu mulai paling awal suatu kegiatan $j$,

$E S_{i}$ adalah waktu mulai paling awal kegiatan predecessor dari kegiatan $j$,

$D_{i j}$ adalah durasi kegiatan $i$ yang merupakan predecessor dari kegiatan $j$

Waktu penyelesaian paling awal EF (Earliest Finish Time) suatu kegiatan $j$ didapatkan dari rumus: $E F_{j}=$

Di mana:

$$
E F_{j}=E S_{j}+D_{j}
$$

$E F_{j}$ adalah waktu penyelesaian paling awal suatu kegiatan $j$,

$E S_{j}$ adalah waktu mulai paling awal dari kegiatan $j$,

$D_{j}$ adalah durasi dari kegiatan $j$

\section{Perhitungan Mundur}

Pada perhitungan mundur dimaksudkan untuk menghitung saat yang paling akhir penyelesaian dan terjadinya dari kegiatan suatu proyek. Waktu penyelesaian paling akhir LF (Latest Finish Time) suatu kegiatan i didapatkan dari rumus:

dimana:

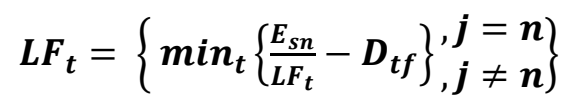

$L F_{t}$ adalah waktu penyelesaian paling akhir suatu kegiatan $i$,

$E_{s n}$ adalah waktu mulai paling awal dari kegiatan $n$,

$L F_{t}$ adalah waktu penyelesaian paling akhir kegiatan successor dari kegiatan $i$,

$N_{t f}$ adalah durasi kegiatan $j$ yang merupakan successor dari kegiatan $i$

Waktu mulai paling akhir LS (Latest Start Time) suatu kegiatan $i$ didapatkan dari rumus:

dimana:

$$
L S_{t}-L F_{t}-D_{t}
$$

$L S_{t}$ adalah waktu mulai paling akhir suatu kegiatan ke- $i$,

$L F_{t}$ adalah waktu penyelesaian paling akhir dari kegiatan $i$,

$D_{t}$ adalah durasi dari kegiatan $i$ ini:

Suatu kegiatan berada di jalur kritis bila kegiatan tersebut memenuhi ketiga kondisi berikut

$$
\begin{aligned}
& \mathrm{ES}=\mathrm{LS} \\
& \mathrm{EF}=\mathrm{LF} \\
& \mathrm{LF}-\mathrm{ES}=\text { Durasi Kegiatan }
\end{aligned}
$$

Kondisi ini sebenarnya menyatakan bahwa tidak ada waktu senggang atau waktu mengambang antara awal tercepat (penyelesaian) dan awal terakhir (penyelesaian) dari kegiatan kritis yang bersangkutan.

\section{Metode Critical Chain Project Management (CCPM)}

Critical Chain Project Management (CCPM) merupakan metode penjadwalan proyek yang diperkenalkan oleh Goldratt pada tahun 1997, namun penggunaannya kurang dimanfaatkan dalam proyek konstruksi di Indonesia [8]. Metode CCPM melakukan pendekatan yang berbeda dalam perencanaan waktu dengan metode pemodelan dan analisa manajemen proyek konvensional. Salah satu penyebab utama rendahnya kinerja perencanaan proyek konvensional adalah besarnya tambahan 
safety time saat penjadwalan waktu . Dengan pertimbangan untuk mencegah proyek dari risiko keterlambatan, tim yang terlibat di proyek menambahkan safety time dalam estimasi waktu setiap aktivitasnya. Penanggung jawab aktivitas memperbesar safety time pada jadwal pekerjaannya untuk mengantisipasi jika terjadi kondisi terburuk yang tidak terduga sebelumnya. Masalah penambahan safety time yang berlebihan inilah yang diperbaiki oleh metode CCPM [9].

Penyelesaian aktivitas-aktivitas individual proyek bukanlah target utama, sebab metode CCPM lebih memprioritaskan kesuksesan proyek secara keseluruhan. Sehingga metode CCPM menghilangkan safety time untuk aktivitas-aktivitas individual dan memfokuskan pada penyelesaian critical chain proyek. Untuk menjamin critical chain tepat waktu, metode CCPM mengganti safety time dengan buffer time. Buffer time terdiri dari feeding buffer dengan project buffer. Feeding buffer adalah waktu peyangga yang menghubungkan aktifitas non-critical chain dengan aktivitas critical chain. Selain itu feeding buffer juga berfungsi sebagai waktu cadangan jika terdapat keterlambatan pada aktifitas non-critical chain. Project buffer adalah waktu penyangga yang di letakkan di akhir critical chain suatu proyek sebagai cadangan waktu untuk keseluruhan proyek. Kedua buffer time inilah yang akan menjamin critical chain dan integritas jadwal proyek secara keseluruhan [9].

\section{Estimasi Tugas}

Ketika kita diminta untuk mengestimasi tugas coba tanya diri kita sendiri apakah tugas tersebut familiar bagi kita. Kita berpikir tentang tugas tersebut dan usaha yang dibutuhkan dan memutuskan kita dapat menyelesaikan tugas dalam 5 hari. Kemudian, kita berpikir lagi. Bisa saja ada beberapa hal yang tidak familiar dalam tugas tersebut. Kita khawatir tentang kemungkinan adanya interupsi dari pekerjaan yang tidak direncanakan sebelumnya. Akhirnya, kita ingin memastikan untuk tidak melampaui perkiraan waktu. Berdasarkan semua ketidakpastian ini, akhirnya kita memutuskan dapat mengerjakan tugas tersebut dalam 10 hari.

Estimasi tugas dalam Critical Chain membutuhkan perubahan perilaku individu dan perusahaan agar bisa berhasil. Kita menghilangkan hidden safety dalam waktu penyelesaian tugas. Karena safety di sini tersembunyi, kita harus mengembangkan suatu budaya organisasi untuk menghilangkan ketakutan untuk menghilangkan safety ini dari estimasi tugas.

Menurut [10] menyebutkan bahwa filosofi CCPM terdiri dari lima(5) bagian, yaitu:

1. Perkiraan waktu tiap aktivitas

2.Mendefinisikan dan menghitung criticalchain

3.Mendefinisikan, menempatkan dan menentukan besarnya buffer

4.Pembagian Sumber daya manusia

Metode ini menggunakan dua parameter durasi/waktu.Parameter pertama adalah durasi yang masih memiliki waktu cadangan untuk melindungi ketidakpastian dalam keterlambatan sumber daya, dilambangkan dengan huruf S (safe estimate). Parameter kedua dilambangkan dengan huruf A, di mana durasi yang terbentuk tanpa waktu cadangan. Pada penelitian kali ini, A diasumsikan sebagai durasi yang memiliki rate output maksimal. Sebagai batasan tambahan, diasumsikan bahwa semua aktivitas bekerja pada taraf maksimal, tidak ada gangguan dari faktor eksternal. Perbedaan pada kedua parameter (D), dirumuskan sebagai berikut:

$$
D=S-A
$$

Di mana

$\mathrm{A}=$ durasi yang terbentuk tanpa waktu cadangan.

$\mathrm{S}$ = durasi yang masih memiliki waktu cadangan untuk melindungi ketidakpastian dalam keterlambatan sumber daya (Safety time).

Di mana besarnya dipengaruhi oleh variasi pada durasi aktivitas. Besar buffer yang dibutuhkan kemudian didefinisikan sebagai jumlah akar kuadrat variasi masing-masing aktivitas. Metode ini memberikan asumsi bahwa masing-masing aktivitas proyek adalah independent.

Asumsikan setiap aktivitas akan diselesaikan pada selang kepercayaan sebesar 90-98\%, ditentukan pula bahwa perbedaan waktu yang direncanakan dengan kenyataan akan berada pada nilai $2 \mathrm{SD}$ (standar deviasi). Untuk masing-masing aktivitas pemakanan buffer dilambangkan dengan i, besarnya standar deviasi diberikan pada rumus berikut: 


$$
\left(\frac{\left(S_{i}-A_{i}\right)}{2}\right)
$$

Dengan nilai $S_{i}$ adalah waktu keluaran terburuk dan $A_{i}$ adalah waktu rata-rata. Asumsi selanjutnya, besarnya buffer dirumuskan sebagai berikut:

$$
B=2 \times \sqrt{\left(\frac{S_{1}-A_{1}}{2}\right)^{2}+\left(\frac{S_{2}-A_{2}}{2}\right)^{2} \ldots+\left(\frac{S_{i}-A_{i}}{2}\right)^{2}}
$$

Pada metode critical chain tersebut, buffer di letakkan di beberapa tempat tertentu, antara lain:

\section{FeedingBuffer}

Pada rangkaian nun critical chain, atau disebut dengan rantai krisis. Buffer di sini dimaksud untuk menjaga rantai critical chain dari pengaruh variasi rantai non krisis tadi. Pada rangkaian $C C P M$ yang baru dibentuk dengan durasi tanpa aktivitas cadangan, diteruskan dengan penempatan buffer, yang diimbangi dengan membuat stabil beban pekerja terlebih dahulu. Pada perencanaan dengan menggunakan metode ini, feeding buffer diletakkan pada tiap akhir rantai non kritis yang akan menuju rantai kritis [9].

\section{Project Buffer}

Pada akhir rantai kritis, terdapat penyangga yang diletakkan pada akhir criticalchain, dimana besarnya ditentukan 30-50\% panjang critical chain. Namun karena standar deviasi buffer tidak terlalu lebar, maka penentuannya dilakukan dengan menjumlahkan buffer pada masing-masing aktivitas di lintasan kritis. Besarnya buffer proyek yang terbentuk pada setiap proyek berbeda, meskipun ketiganya memiliki struktur yang hampir identik [9].

\section{Student Syndrome}

Student Syndrom, dapat diilustrasikan sebagai berikut seorang dosen memberikan tugas kelas yang harus selesai dalam 1 Minggu kepada para mahasiswanya. Kemudian para mahasiswa protes dan mengatakan bahwa tugas tersebut sangat berat dan mereka membutuhkan lebih banyak waktu untuk mengerjakannya. Dosen tersebut setuju dan memberi tambahan waktu. Kemudian, ketika Mahasiswa melihat kembali bagaimana mereka dapat mengerjakan tugas itu dengan tambahan waktu yang diberikan, mereka berpikir bahwa mereka memiliki cukup banyak waktu yang aman untuk mengerjakan sehingga mereka menetapkan awal pengerjaan sampai pada menit-menit terakhir. Dari Ilustrasi tersebut kita bisa melihat bahwa student syndrome ini dapat mempengaruhi tugas kita dan proyek secara keseluruhan [9].

\section{Parkinson's Law}

Dapat diilustrasikan sebagai berikut, jika sebuah proyek tradisional ditekankan untuk tidak terlambat, namun para pekerja tidak mendapat promosi bila dapat menyelesaikan tugas atau proyek lebih cepat dari tenggat waktu yang ditentukan. Kenyataan ini mendorong efek dari hidden safety, student syndrome dan parkinsons's las [9].

\section{Multi- tasking}

Kebanyakan dari kita bekerja dalam lingkungan multi-project. Kita mungkin pernah mengalami menghentikan kerja pada satu tugas untuk dapat menyelesaikan tugas dari proyek lain. sering kita bertanya-tanya apakah tindakan lompat sana-sini sudah benar karena mengakibatkan kurang fokus dan tidak efisien. Ini menjadi salah satu kendala seorang pekerja tidak dapat menyelesaikan pekerjaannya tepat waktu [9].

\section{No Early Finishes}

Kalau kita perhatikan biasanya penyelesaian tugas selalu tepat waktu atau terlambat,jarang sekali terjadi lebih cepat dari jadwal. Ini disebabkan beberapa hal di atas (Student Syndrom dan Parkinson law) yang mengakibatkan sebuah jadwal jarang sekali selesai lebih cepat. Jika kita 
menyelesaikan tugas lebih cepat, kemungkinan kita akan dituduh memanipulasi estimasi bukannya diberi penghargaan atas penyelesaian proyek yang lebih cepat dari tenggat waktu [9] .

\section{Backward Planning}

Pada saat Critical Chain Project Management (CCPM) diaplikasikan pada perencanaan critical chain, kita mengembangkan rencana mundur dari target pada proyek kita. Ketika kita menandatangani proyek baru kita biasanya diberi tahu kapan hasil-hasil di harapkan harus tersedia. Untuk itu kita perlu menentukan kapan kita harus memulai bekerja untuk mencapai target akhir. Ini bukan berartiu kita berpikir mundur. Melainkan ini berarti ketika kita menjabarkan proyek kita dengan tugas-tugas, durasi dan hubungan ketergantungan. Ketika perencanaan selesai dilaksanakan, perkiraan tanggal proyek dimulai menunjukkan tanggal maksimal. Kita harus memulai proyek agar memenuhi target akhir. berdasarkan pengalaman yang sudah ada, kita memulai proyek dengan tujuan dan bekerja secara mundur, maka kecil kemungkinan kita akan menmbahkan tugas-tugas yang tidak mempunyai nilai tujuan [9].

\section{As-Late -As Possible Sheduling}

Dalam penjadwalan Critical Path traditional,tugas-tugas di jadwalkan secepat mungkin (As Soon As Possible) dari tanggal proyek dimulai. Penjadwalan ini menempatkan kerja sedekat mungkin dengan awal dari jadwal kita. Dalam perencanaan Critical Chain,tugas-tugas di jadwalkan selambat mungkin (As Late As Possible) berdasarkan tanggal akhir target. Penjadwalan ini menempatkan kerja sedekat mungkin dengan akhir scehedule kita. Dengan CCPM kita dapat memasukkan buffer / penyangga pada titik kunci dalam rencana proyek yang akan berfungsi sebagai penyerap untuk menjaga waktu batas akhir proyek terhadap peningkatan waktu pengerjaan suatu tugas [9].

\section{METODE PENELITIAN}

Dalam penyelesaian untuk mendapatkan penjadwalan CCPM pada Proyek Apartamen Menara Rungkut, terdapat beberapa tahapan-tahapan yang harus dikerjakan terlebih dahulu. Untuk lebih jelas dan menganai beberapa tahapan tersebut, maka dapat dibuat Diagram Alir seperti pada Gambar 1.

\section{HASIL DAN PEMBAHASAN}

Perhitungan Produktivitas dengan menggunakan Metode Critical Chain Project Management digunakan untuk menghitung nilai standar time suatu pekerjaan. Penggunaan metode ini dilakukan dengan pengumpulan data di lapangan, bagaimana suatu pekerjaan dilakukan dari tahap awal hingga tahap akhir. Analisa CCPM antara lain:

1. Penentuan Hubungan Keterkaitan Pekerjaan

2. Penentuan Produktivitas

3. Pengalokasian Sumber Daya

4. Penentuan Durasi Tampa Waktu Cadangan

\section{Penentuan Hubungan Keterkaitan Pekerjaan}

Hubungan keterkaitan pekerjaan pada $C C P M$ ini akan sama seperti pada $C P M$. pada penjadwalan CCPM akan dilakukan levelling guna menghindar dari adanya waktu pengerjaan terjadi secara bersamaan (multitasking) dalam hari yang sama. Hal ini akan terkait dan akan dibahas pada pengalokasian sumber daya. 


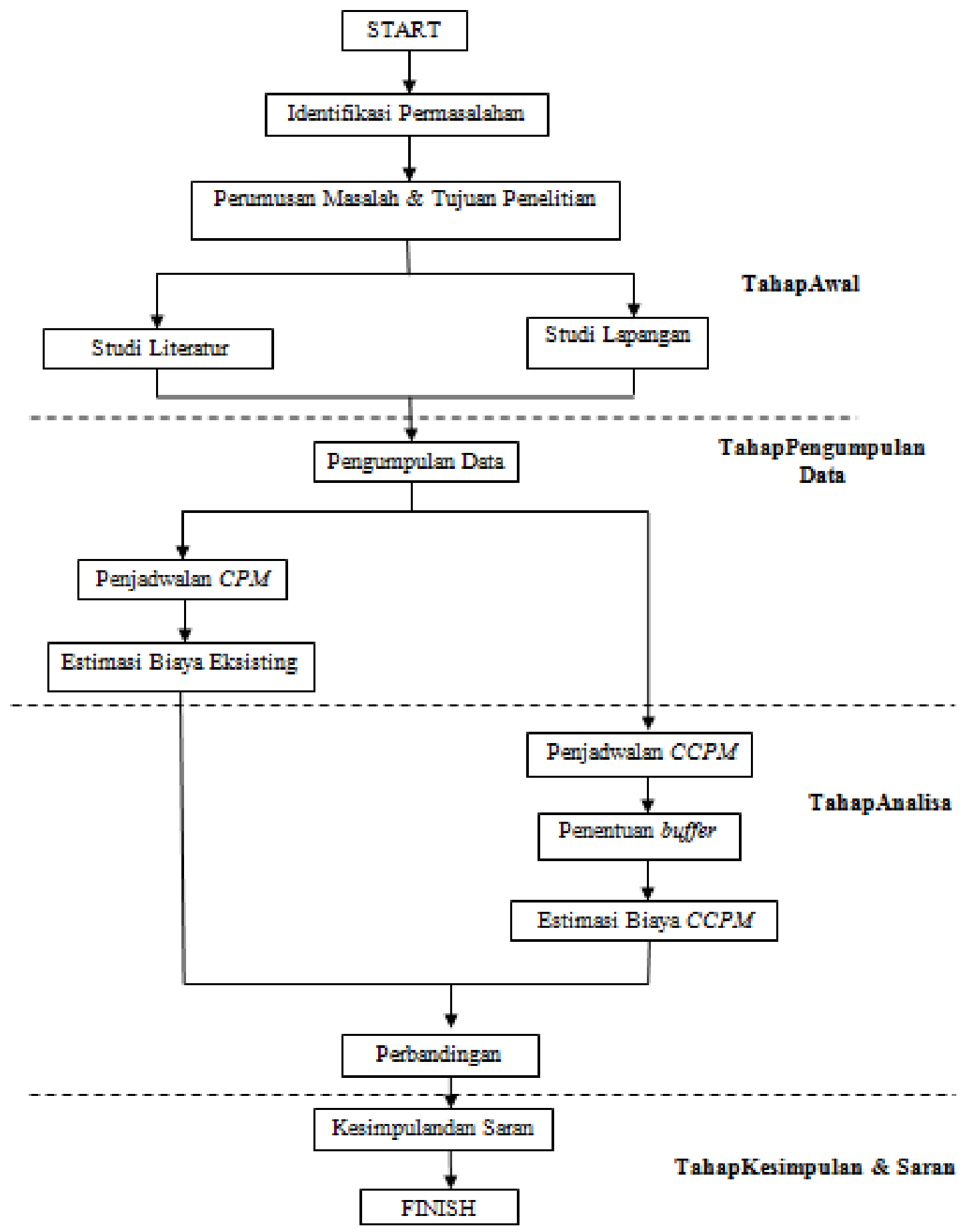

Gambar 1. Flowchart Metode Penelitian 
Tabel 1. Hubungan Keterkaitan Aktivitas

\begin{tabular}{|c|c|c|}
\hline No & Aktivitas & Predecessor \\
\hline $\begin{array}{l}1 \\
2 \\
3 \\
4 \\
5\end{array}$ & $\begin{array}{l}\text { KOLOM } \\
\text { Pembesian } \\
\text { Pasang Bekisting } \\
\text { Pembongkaran Bekisting } \\
\text { Pengecoran } \\
\text { Perawatan Beton }\end{array}$ & $\begin{array}{c}\text { A1 } \\
\text { A4+10d } \\
\text { A2 } \\
\text { A3 }\end{array}$ \\
\hline $\begin{array}{l}1 \\
2 \\
3 \\
4 \\
4 \\
5 \\
6 \\
7\end{array}$ & $\begin{array}{l}\text { SLAB \& BEAM } \\
\text { Pasang Bekisting } \\
\text { Pasang Bondeks } \\
\text { Pembongkaran Bekisting } \\
\text { Pembesian } \\
\text { Pasang Wirmesh } \\
\text { Pengecoran } \\
\text { Perawatan Beton }\end{array}$ & $\begin{array}{c}\text { A4 } \\
\text { B1SS } \\
\text { B6+10d } \\
\text { B1 } \\
\text { B4SS } \\
\text { B5 } \\
\text { B3 }\end{array}$ \\
\hline $\begin{array}{l}1 \\
2 \\
3 \\
4 \\
5\end{array}$ & $\begin{array}{l}\text { Tangga } \\
\text { Pasang Bekisting } \\
\text { Pembongkaran Bekisting } \\
\text { Pembesian } \\
\text { Pengecoran } \\
\text { Perawatan Beton }\end{array}$ & $\begin{array}{c}\text { B3 } \\
\text { C4+10d } \\
\text { C1 } \\
\text { C3 } \\
\text { C2 }\end{array}$ \\
\hline
\end{tabular}

Lantai Kedua
\begin{tabular}{|l|l|c|}
\hline \multicolumn{1}{|c|}{ No } & \multicolumn{1}{|c|}{ Aktivitas } & Predecessor \\
\hline D & KOLOM & \\
& & A1 \\
1 & Pembesian & D1 \\
2 & Pasang Bekisting & A +10 d \\
3 & Pembongkaran Bekisting & A2 \\
4 & Pengecoran & A3 \\
5 & Perawatan Beton & \\
\hline E & lLAB \& BEAM & \\
& & B1 \\
1 & Pasang Bekisting & E1SS \\
2 & Pasang Bondeks & E6+10d \\
3 & Pembongkaran Bekisting & E1 \\
4 & Pembesian & E 4 SS \\
5 & Pasang Wirmesh & E5 \\
6 & Pengecoran & E3 \\
7 & Perawatan Beton & \\
& & \\
\hline F & Tangga & C1 \\
& Pasang Bekisting & F4+10d \\
2 & Pembongkaran Bekisting & F1 \\
3 & Pembesian & F3 \\
4 & Pengecoran & F2 \\
5 & Perawatan Beton & \\
\hline
\end{tabular}

\section{Penentuan Produktivitas}

Dari aktivitas-aktivitas awal yang telah ditentukan di atas, kemudian dicari produktivitasproduktivitas pekerjaan-pekerjaan tersebut agar perhitungan durasi nantinya dapat benar-benar real sesuai dengan keadaan produktivitas di lapangan. Penentuan produktivitas adalah berdasarkan standard produktivitas sumber daya di lapangan per jam yang nantinya akan dikonversikan dalam bentuk per hari. (Dalam penelitian ini 1 hari $=8$ jam). Tabel 2 Menunjukkan contoh perhitungan produktivitas.

Tabel 2. Perhitungan Produktivitas

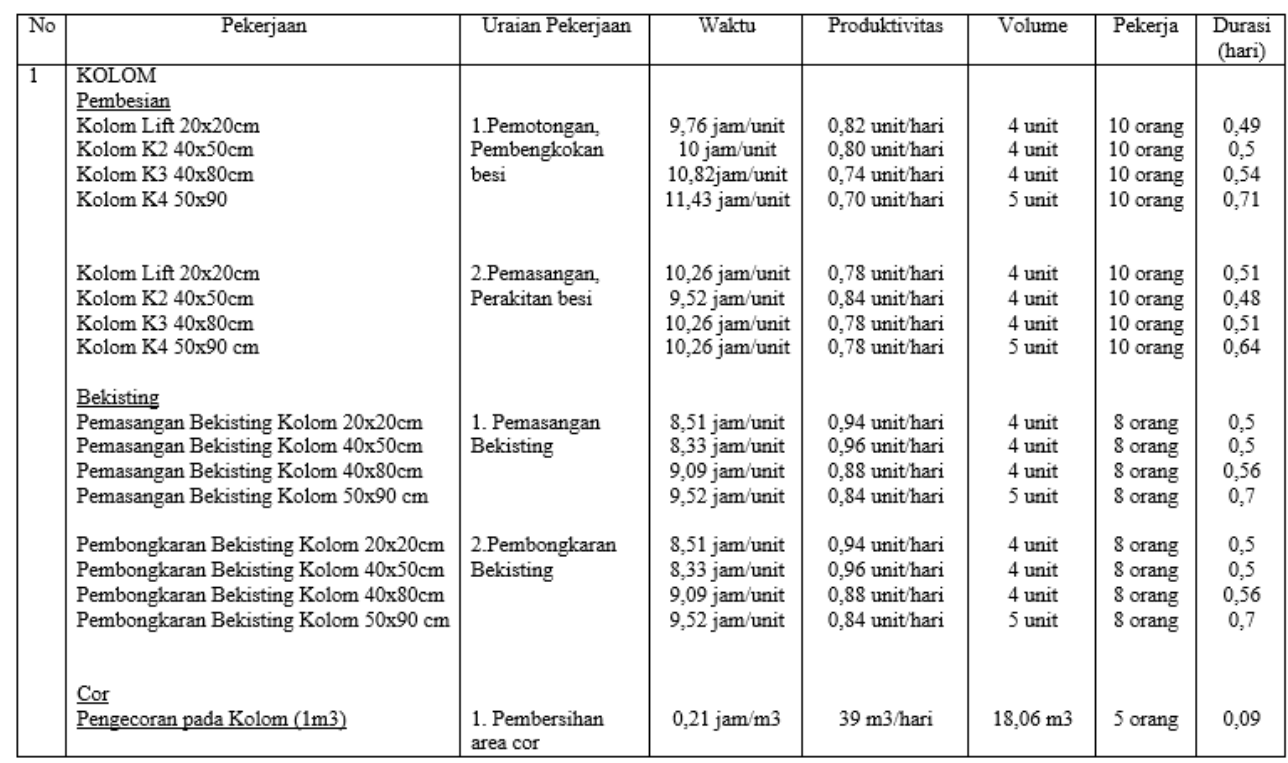




\section{Pengalokasian Sumber Daya}

Sumber daya dialokasikan sesuai dengan pekerjaannya dan sesuai dengan urutan hubungan keterkaitan pekerjaannya. Tenaga-tenaga kerja yang merupakan multi tasking perlu perhatian yang lebih khusus untuk mengalokasikan agar dapat terhindar dari overallocated, yaitu dengan cara Resource Leveling.

Tabel 3. Tampilan resource sheet pada penjadwalan CPM

\begin{tabular}{|l|l|l|l|r|r|r|}
\hline & Work & & $T$ & 16 Rp80,000/day & Rp0/hr & Rp0 Prorated \\
\hline
\end{tabular}

Tabel 4. Tampilan resource sheet pada penjadwalan CCPM

\begin{tabular}{|c|c|c|c|c|c|c|c|c|c|c|c|c|c|c|}
\hline & (i) & Resource Name & Type & $\checkmark$ & Material & - Initials & - & Group - & Max. Units & - Std. Rate & Ovt. Rate ${ }^{-}$ & Cost/Use ${ }^{-}$ & Accrue - & Base \\
\hline 1 & & Tenaga Bekisting Kolom & Work & & & $T$ & & & & 8 रр80,000/day & $\mathrm{Rp} 0 / \mathrm{hr}$ & Rpo & Prorated & Standard \\
\hline 2 & & Tenaga Bekisting Slab \& Beam & Work & & & $T$ & & & & 18 २p80,000/day & $\mathrm{Rp} 0 / \mathrm{hr}$ & $\mathrm{RpO}$ & Prorated & Standard \\
\hline 3 & & Tenaga Bekisting Tangga & Work & & & $T$ & & & & 4 2p80,000/day & $\mathrm{Rp} 0 / \mathrm{hr}$ & $\mathrm{Rpo}$ & Prorated & Standard \\
\hline 4 & & Tenaga Pembesian Kolom & Work & & & $T$ & & & & 10 रр80,000/day & $\mathrm{Rp} 0 / \mathrm{hr}$ & $\mathrm{RpO}$ & 0 Prorated & Standard \\
\hline 5 & & Tenaga Pasang Bondeks & Work & & & T & & & & 3 रp80,000/day & $\mathrm{Rp} 0 / \mathrm{hr}$ & Rpo & 0 Prorated & Standard \\
\hline 6 & & Tenaga Pasang Wirmesh & Work & & & $T$ & & & & 3 रp80,000/day & $\mathrm{Rp} 0 / \mathrm{hr}$ & $\mathrm{Rpo}$ & 0 Prorated & Standard \\
\hline 7 & (1) & Tenaga Pembesian Slab \& Beam & Work & & & $T$ & & & & 20 tp80,000/day & $\mathrm{Rp} 0 / \mathrm{hr}$ & Rpo & Prorated & Standard \\
\hline 8 & & Tenaga PembesianTangga & Work & & & T & & & & 3 रp80,000/day & $\mathrm{Rp} 0 / \mathrm{hr}$ & $\mathrm{Rpo}$ & Prorated & Standard \\
\hline 9 & (1) & Tenaga Pengecoran Kolom & Work & & & $T$ & & & & 5 :p80,000/day & $\mathrm{Rp} 0 / \mathrm{hr}$ & Rpo & Prorated & Standard \\
\hline 10 & & Tenaga Pengecoran Slab \& Beam & Work & & & $T$ & & & & 12 रр80,000/day & $\mathrm{Rp} 0 / \mathrm{hr}$ & $\mathrm{Rpo}$ & Prorated & Standard \\
\hline 11 & & Tenaga Pengecoran Tangga & Work & & & $T$ & & & & 3 रр80,000/day & $\mathrm{Rp} 0 / \mathrm{hr}$ & $\mathrm{Rpo}$ & Prorated & Standard \\
\hline 12 & (1) & Tenaga Pembongkaran Bekisting ko & Work & & & T & & & & 6 tp80,000/day & $\mathrm{Rp} 0 / \mathrm{hr}$ & Rpo & Prorated & Standard \\
\hline 13 & (1) & Tenaga Pembongkaran Bekisting Sla & Work & & & $T$ & & & & 14 !p80,000/day & $\mathrm{Rp} 0 / \mathrm{hr}$ & Rpo & Prorated & Standard \\
\hline 14 & (1) & Tenaga Pembongkaran Bekisting TaI & 1 Work & & & $T$ & & & & 4 !p80,000/day & $\mathrm{Rp} 0 / \mathrm{hr}$ & Rpo & Prorated & Standard \\
\hline 15 & (1) & Tenaga Perawatan Kolom & Work & & & $T$ & & & & 4 !p80,000/day & $\mathrm{Rp} 0 / \mathrm{hr}$ & Rp0 & Prorated & Standard \\
\hline 16 & & Tenaga Perawatan Slab \& Beam & Work & & & $T$ & & & & 10 ₹p80,000/day & $\mathrm{Rp} 0 / \mathrm{hr}$ & $\mathrm{Rpo}$ & Prorated & Standard \\
\hline 17 & & Tenaga Perawatan Tangga & Work & & & T & & & & 5 रp80,000/day & $\mathrm{Rp} 0 / \mathrm{hr}$ & $\mathrm{Rpo}$ & Prorated & Standard \\
\hline
\end{tabular}

Dari gambar tampilan Tabel 4 tersebut sudah tidak ada multitasking lagi. Hal ini berbeda dengan

\begin{tabular}{|c|c|c|c|c|c|c|c|}
\hline Tenaga Bekisting Kolom & Work & $T$ & 16 Rp80,000/day & $\mathrm{Rp} 0 / \mathrm{hr}$ & Rpo & Prorated & Standard \\
\hline Tenaga Bekisting Slab \& Beam & Work & $T$ & 18 रp80,000/day & $\mathrm{Rp} 0 / \mathrm{hr}$ & Rpo & Prorated & Standard \\
\hline Tenaga Bekisting Tangga & Work & $T$ & 4 रp80,000/day & $\mathrm{Rp} 0 / \mathrm{hr}$ & $\mathrm{RpO}$ & Prorated & Standard \\
\hline Tenaga Pembesian Kolom & Work & $T$ & 10 रp80,000/day & $\mathrm{Rp} 0 / \mathrm{hr}$ & Rpo & Prorated & Standard \\
\hline Tenaga Pasang Bondeks & Work & T & 3 रp80,000/day & $\mathrm{Rp} 0 / \mathrm{hr}$ & $\mathrm{Rpo}$ & Prorated & Standard \\
\hline Tenaga Pasang Wirmesh & Work & $T$ & 9 रp $80,000 /$ day & $\mathrm{Rp} 0 / \mathrm{hr}$ & Rpo & Prorated & Standard \\
\hline Tenaga Pembesian Slab \& Beam & Work & T & 40 Rp80,000/day & $\mathrm{Rp} 0 / \mathrm{hr}$ & Rpo & Prorated & Standard \\
\hline Tenaga PembesianTangga & Work & $T$ & 3 २p80,000/day & $\mathrm{Rp} 0 / \mathrm{hr}$ & Rpo & Prorated & Standard \\
\hline Tenaga Pengecoran Kolom & Work & T & 10 रp80,000/day & $\mathrm{Rp} 0 / \mathrm{hr}$ & Rpo & Prorated & Standard \\
\hline Tenaga Pengecoran Slab \& Beam & Work & T & 12 रp80,000/day & $\mathrm{Rp} 0 / \mathrm{hr}$ & $\mathrm{Rpo}$ & Prorated & Standard \\
\hline Tenaga Pengecoran Tangga & Work & $T$ & 3 रp80,000/day & $\mathrm{Rp} 0 / \mathrm{hr}$ & Rpo & Prorated & Standard \\
\hline Tenaga Pembongkaran Bekisting kolor & Work & T & 20 रp80,000/day & $\mathrm{Rp} 0 / \mathrm{hr}$ & Rpo & Prorated & Standard \\
\hline Tenaga Pembongkaran Bekisting Slab & Work & T & 28 रp80,000/day & $\mathrm{Rp} 0 / \mathrm{hr}$ & Rpo & Prorated & Standard \\
\hline Tenaga Pembongkaran Bekisting Tang & Work & $T$ & 4 रp80,000/day & $\mathrm{Rp} 0 / \mathrm{hr}$ & Rpo & Prorated & Standard \\
\hline Tenaga Perawatan Kolom & Work & T & 12 रp80,000/day & $\mathrm{Rp} 0 / \mathrm{hr}$ & $\mathrm{Rpo}$ & Prorated & Standard \\
\hline Tenaga Perawatan Slab \& Beam & Work & T & 10 Rp80,000/day & $\mathrm{Rp} 0 / \mathrm{hr}$ & Rpo & Prorated & Standard \\
\hline Tenaga Perawatan Tangga & Work & T & 5 Rp80,000/day & $\mathrm{Rp} 0 / \mathrm{hr}$ & $\mathrm{Rp} 0$ & Prorated & Standard \\
\hline
\end{tabular}


Tabel 4. Tampilan resource sheet pada penjadwalan CCPM

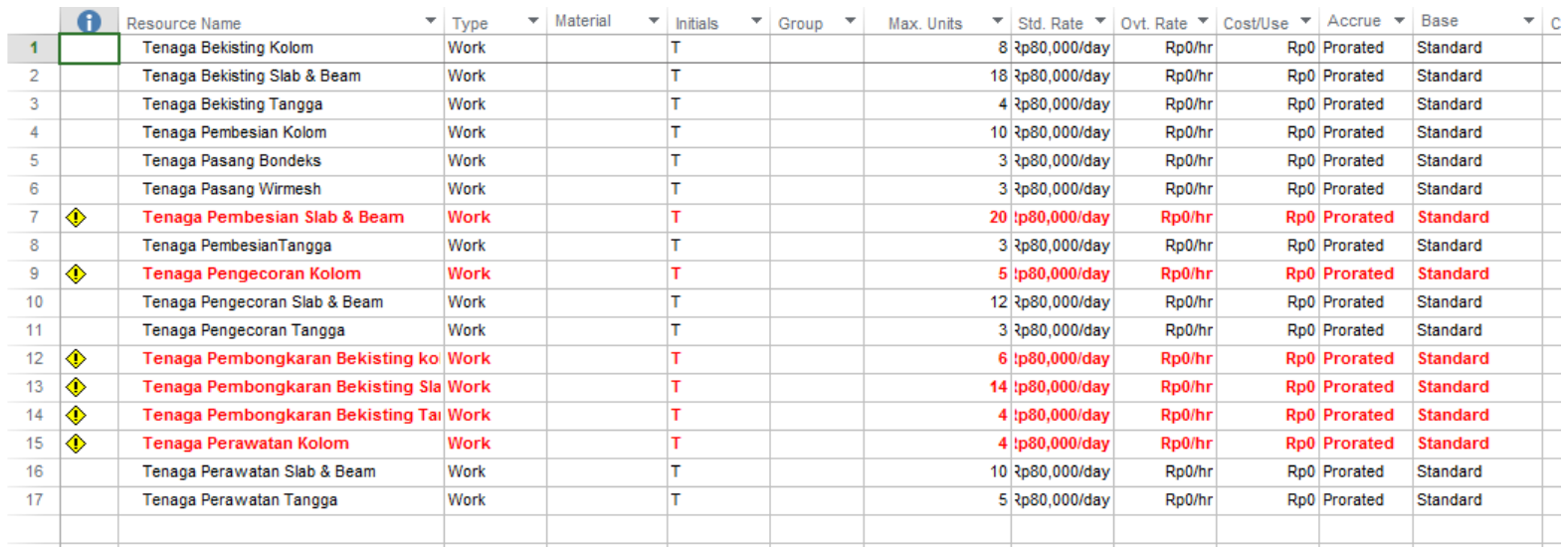

yang merupakan tampilan resources sheet pada penjadwalan CPM dari proyek, karena pada gambar tersebut masih ada banyak multitasking yang ditunjukkan dengan tulisan berwarna merah atau tanda peringatan.

\section{Penentuan Durasi Tampa Waktu Cadangan}

Hal selanjutnya yang penting sekali dilakukan adalah penentuan durasi sebenarnya tanpa penambahan cadangan waktu. Besarnya durasi sebenarnya ini dapat dihitung dengan cara membagi volume dengan produktivitas tenaga kerja dalam menyelesaikan pekerjaan tersebut. Nilai produktivitas yang diambil di sini adalah nilai sesuai dengan hasil perhitungan produktivitas yang sudah di alokasikan feading buffer dan project buffer. 
Tabel 5. Perhitungan Feeding Buffer

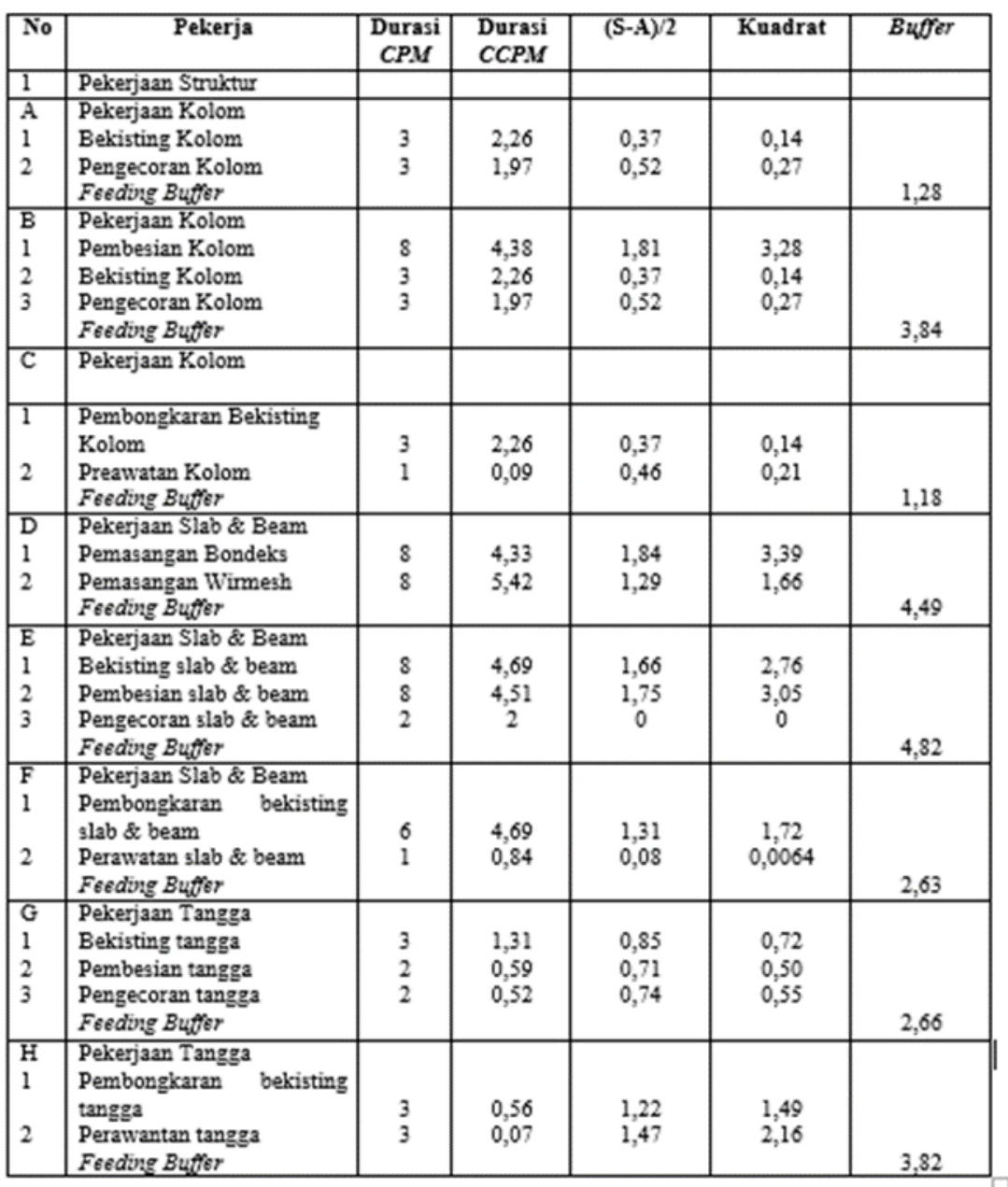

Tabel 6. Perhitungan Project Buffer

\begin{tabular}{|l|l|c|c|c|c|c|}
\hline No & \multicolumn{1}{|c|}{ Pekerja } & $\begin{array}{c}\text { Durasi } \\
\text { CPM }\end{array}$ & $\begin{array}{c}\text { Durasi } \\
\text { CCPM }\end{array}$ & (S-A)/2 & Kuadrat & Buffer \\
\hline 1 & Pekerjaan Struktur & & & & & \\
\hline A & Pekerjaan Kolom & 8 & 4,38 & 1,81 & 3,3 & \\
1 & Pembesian & 3 & 2,26 & 0,37 & 0,14 & \\
2 & Pasang Bekisting & 3 & 2,26 & 0,371 & 0,14 & \\
3 & PembongkaranBekisting & 3 & 1,97 & 0,5 & 0,25 & \\
4 & Pengecoran & 1 & 0,09 & 0,4 & 0,16 & \\
5 & Perawatan Beton & 8 & 4,69 & 1,7 & 2,9 & \\
B & Pekerjaan Slab \& Beam & 8 & 4,33 & 1,8 & 3,2 & \\
1 & Pasang Bekisting & 6 & 4,69 & 0,7 & 0,49 & \\
2 & Pasang Bondeks & 8 & 4,51 & 1,7 & 2,9 & \\
3 & Pembongkaran Bekistin & 8 & 5,42 & 0,74 & 0,5 & \\
4 & Pembesian & 2 & 2 & 0 & 0 & \\
5 & Pasang Wirmesh & 1 & 0,84 & 0,08 & 0,0064 & \\
6 & Pengecoran & 3 & 1,31 & 0,8 & 0,6 & \\
7 & Perawatan Beton & 3 & 0,56 & 1,2 & 1,44 & \\
C & Tangga & 2 & 0,59 & 0,7 & 0,49 & \\
1 & Pasang Bekisting & 3 & 0,52 & 1,24 & 0,49 & \\
2 & Pembongkaran Bekistin & 1 & 0,07 & 0,47 & 1,54 & \\
3 & Pembesian & & & & 0,22 & \\
4 & Pengecoran & & & & & \\
5 & Perawatan Beton & & & & \\
& & & & & \\
& Project Buffer & & & & \\
& & & & & \\
& & & & & \\
& & & & & \\
\end{tabular}


Setelah menentukan aktivitas awal, menentukan produktivitas, menentukan hubungan keterkaitan pekerjaan, pengalokasian sumber daya dan menentukan durasi, maka dapatlah dibuat suatu bentuk pemodelan awal CCPM gambar bentuk pemodelan awal pada pekerjaan struktur atas dapat dilihat pada Gambar 2

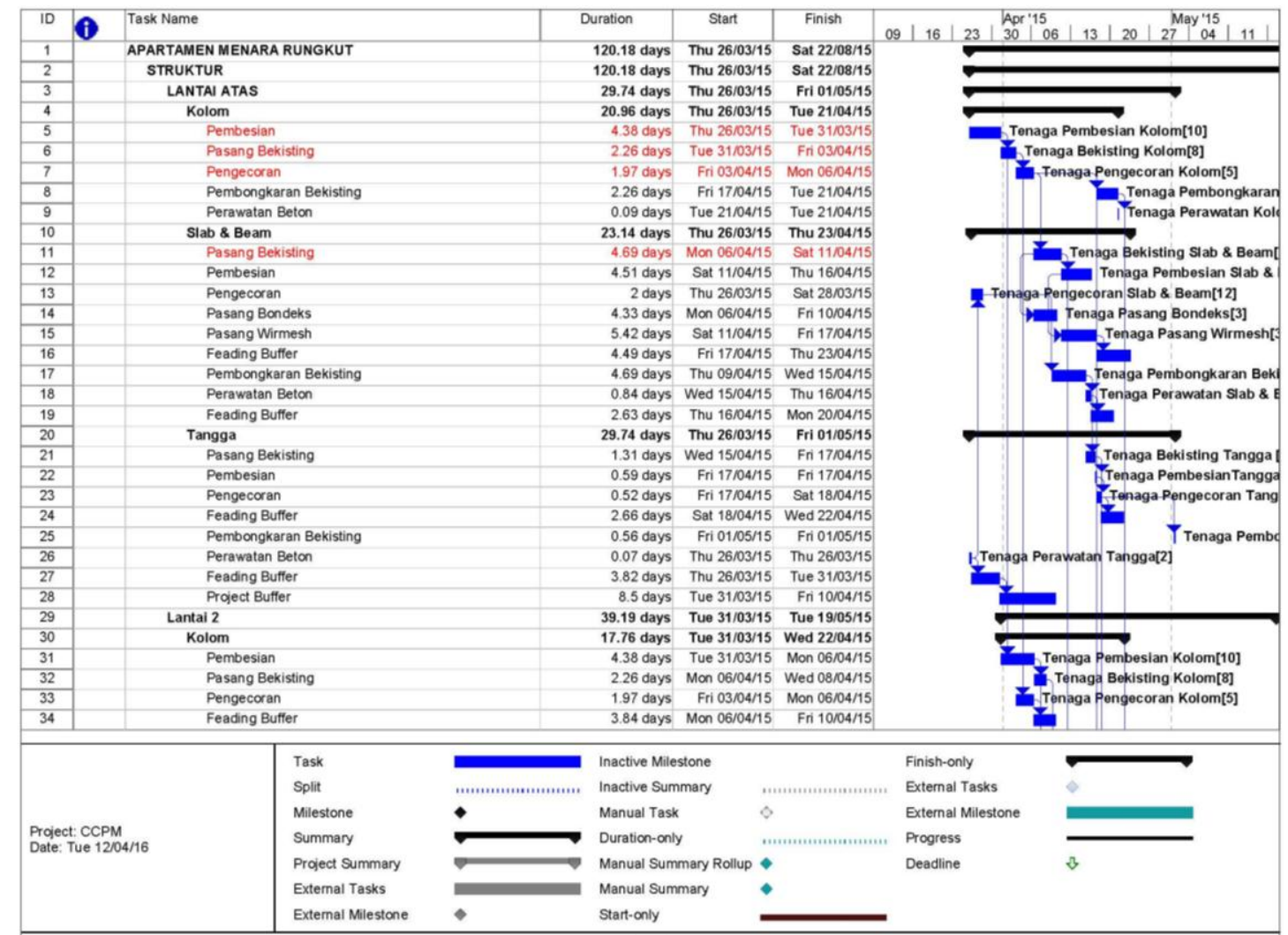

Gambar 2. Penjadwalan CCPM

\section{KESIMPULAN}

Berdasarkan keseluruhan hasil analisa yang telah dilakukan dapat disimpulkan bahwa, dari uraian di atas untuk segi waktu diperoleh hasil bahwa durasi untuk pekerjaan Struktur atas pada penjadwalan Critical Path Methodadalah 169 hari, sedangkan durasi untuk pekerjaan Struktur atas pada penjadwalan Critical Chain Project Management adalah 120,18 hari atau 121 hari.

\section{DAFTAR PUSTAKA}

[1] B. Santosa. 1997. Manajemen Proyek. Yogyakarta: Graha Ilmu.

[2] A. Husen. 2009. Manajemen Proyek., Yogyakarta: CV.Anddi Offset.

[3] I. Dispohusodo. 1996. Manajemen Proyek dan Konstruksi. Yogyakarta: Kanisius.

[4] N. Susanto, R. Purwaningsih dan E. Ardiansyah, 2006. Analisis Jaringan Kerja dan Penentuan Jalur Kritis dengan Critical Path Method-CPM (Studi Kasus Pembangunan Rumah Graha Taman Pelangi Type Milano pada PT Karyadeka Alam Lestari Semarang). J@ TI, I (1): 74-84.

[5] I. Soeharto. 1999. Manajemen Proyek Dari Konsep Sampai Operational Jilid I. Jakarta: Erlangga.

[6] S. Hiller dan G. Lieberman. 1994. Pengantar Riset Operasi. Jakarta: Erlangga.

[7] H. Taha. 1997. Operation Research. Jakarta: Bina Rupa Aksara. 
[8] C. H. Suryansen, W. S. Martanto dan P. Nugraha, 2014. Penentuan Buffer Sizing Dalam Penerapan Critical Chain Project Management pada Sebuah Proyek Konstruksi. Jurnal Dimensi Pratama Teknik Sipil, III (2):1-8

[9] B. Santosa.2009. Manajemen Proyek. Yogyakarta: Graha Ilmu.

[10] J. Ribera. 2003. Putting the core element CCPM into Persective: A general frame work fot Buffer Management. Barcelona: IESE Bussiness School. 